Article

\title{
Integration of Safety Aspects in Modeling of Superheated Steam Flash Drying of Tobacco
}

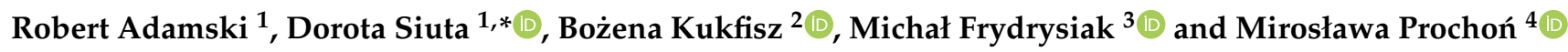 \\ 1 Faculty of Process and Environmental Engineering, Lodz University of Technology, Wolczanska Str. 213, \\ 90-924 Lodz, Poland; robert.adamski@p.lodz.p1 \\ 2 The Main School of Fire Service, Faculty of Security Engineering and Civil Protection, Słowackiego 52/54, \\ 01-629 Warszawa, Poland; bkukfisz@sgsp.edu.pl \\ 3 Faculty of Material Technologies and Textile Design, Lodz University of Technology, St. Zeromskiego 116, \\ 90-924 Lodz, Poland; michal.frydrysiak@p.lodz.pl \\ 4 Faculty of Chemistry, Lodz University of Technology, Stefanowskiego 12/16, 90-924 Lodz, Poland; \\ miroslawa.prochon@p.lodz.pl \\ * Correspondence: dorota.siuta@p.lodz.pl; Tel.: +48-42631-3744
}

Citation: Adamski, R.; Siuta, D.;

Kukfisz, B.; Frydrysiak, M.; Prochoń,

M. Integration of Safety Aspects in

Modeling of Superheated Steam Flash

Drying of Tobacco. Energies 2021, 14,

5927. https://doi.org/10.3390/

en14185927

Academic Editor: Lyes Bennamoun

Received: 11 July 2021

Accepted: 15 September 2021

Published: 18 September 2021

Publisher's Note: MDPI stays neutral with regard to jurisdictional claims in published maps and institutional affiliations.

Copyright: (c) 2021 by the authors. Licensee MDPI, Basel, Switzerland. This article is an open access article distributed under the terms and conditions of the Creative Commons Attribution (CC BY) license (https:// creativecommons.org/licenses/by/ $4.0 /)$

\begin{abstract}
Knowledge of the drying properties of tobacco in high temperatures above $100{ }^{\circ} \mathrm{C}$ and its dust are crucial in the design of dryers, both in the optimization of the superheated-steam-drying process and in the correct selection of innovative explosion protection and mitigation systems. In this study, tobacco properties were determined and incorporated into the proposed model of an expanding superheated steam flash dryer. The results obtained from the proposed model were validated by using experimental data yielded during test runs of an industrial scale of a closed-loop expansion dryer on lamina cut tobacco. Moreover, the explosion and fire properties of tobacco dust before and after the superheated steam-drying process at $160,170,180$, and $190{ }^{\circ} \mathrm{C}$ were experimentally investigated, using a $20 \mathrm{~L}$ spherical explosion chamber, a hot plate apparatus, a Hartmann tube apparatus, and a Godbert-Greenwald furnace apparatus. The results indicate that the higher the drying temperature, the more likely the ignition of the dust tobacco cloud, the faster the explosion flame propagation, and the greater the explosion severity. Tobacco dust is of weak explosion class. Dust obtained by drying with superheated steam at $190{ }^{\circ} \mathrm{C}$ is characterized by the highest value of explosion index amounting to $109 \pm 14 \mathrm{~m} \cdot \mathrm{bar} \cdot \mathrm{s}^{-1}$, the highest explosion pressure rate $(405 \pm 32 \mathrm{bar} / \mathrm{s})$, and the maximum explosion pressure $(6.7 \pm 0.3 \mathrm{bar})$. The prevention of tobacco-dust accumulation and its removal from the outer surfaces of machinery and equipment used in the superheated steam-drying process are highly desirable.
\end{abstract}

Keywords: tobacco; superheated steam; drying; fire; explosion; safety

\section{Introduction}

Drying is a necessary process and the most energy-consuming step in tobacco production. The selection of drying method affects the tobacco's chemical and physical properties and the quality of cigarette smoke [1-3]. Tobacco undergoes drying at least three times in its life before it leaves the cigarette factory. First, the tobacco is cured and dried just after harvesting. This stage is necessary to lower the water activity of green tissue below a lever, ensuring that all microbial activity in the product will be terminated and the product can be handled safely. Thus, the green leaf is dried from ca. $85 \%$ moisture content to $13 \div 18 \%$ in atmospheric air (air-curing) or in heated air (flue-curing). Curing that takes place simultaneously with drying is responsible for developing the necessary sensory characteristics of the product [4]. Second, leaves from farms are processed by tobacco wholesalers. Tobacco leaves are conditioned to $20 \div 22 \%$ and threshed (leaf stem is separated from lamina). Tobacco is then re-dried down to $7 \%$, followed by cooling and remoistening to $11 \%$. In this form, tobacco is baled and ready for export. Third, baled tobacco is rewetted at a cigarette 
factory to restore the plant tissue's elasticity, so that the product can be handled without cracking and generating excessive dust. After resting awhile, the tobacco is shredded, and the cut tobacco is dried again to its final moisture content. In this drying process, tobacco can be simultaneously expanded to increase its filling power (and so reduce tissue density). Most often, an ensemble of expansion tunnel and rotary dryers or a one-stage superheated steam expansion dryer (closed-loop expansion dryer (CLED)) are used [4]. After this stage, the tobacco is conditioned again by adding some additional components (called sauces), which improve flavor and taste. However, the tobacco will no longer be dried in a dryer, but will only lose some moisture (1-2\%) during the cigarette-making process. This paper concerns modeling the drying process of tobacco that takes place in the expanding superheated steam dryer in order to predict the properties of tobacco in high temperatures above $100{ }^{\circ} \mathrm{C}$ and the efficiency of drying systems.

During cigarette production, tobacco dust from processed leaves is generated on equipment near the superheated-steam-drying facility and can result in fire and explosion hazards that can lead to human fatalities, serious injuries, and financial loss. Tobacco dust poses a risk of explosion due to the formation of dust-air mixtures from the sources of emissions and the formation of a dust layer, which may be ignited by self-heating [5]. The ignited layer of dust may then play the role of an ignition source for subsequent explosions. Very often, designers of technological processes do not have sufficient knowledge concerning the basic physical and chemical parameters of materials [6] and their dusts occurring under specific process conditions. Data related to cut tobacco in high temperatures above $100{ }^{\circ} \mathrm{C}$ are scarce and not sufficiently available in the literature [7]. Furthermore, there is no information about the influence of the superheated-steam-drying process on tobacco dust flammability and explosiveness parameters.

The present research is intended to develop a model of an expanding superheated steam flash dryer for cut tobacco incorporating determined tobacco properties (sorption isotherms, sorption isobars, particle morphology, drag coefficient, and heat capacity) and validate the results obtained from the proposed model, using experimental data obtained during test runs of an industrial scale CLED on lamina cut tobacco. Additional explosion and fire properties of dust tobacco, such as maximum explosion pressure, maximum rate of pressure rise, explosion index, minimum explosion concentration, minimum ignition energy, minimum ignition temperature, and limiting oxygen concentration, were determined that are critical for the risk assessment and safety management of dust explosions [8]. Moreover, the influence of the superheated-steam-drying process on tobacco dust flammability and explosiveness parameters was studied. The results obtained are crucial in the design of dryers, including the optimization of the superheated-steam-drying process, the correct selection of innovative explosion protection, and a mitigation system in order to assure the safety of working people.

\section{Materials and Methods}

\subsection{Materials}

Virginia tobacco was used as the raw material in this study. Samples of tobacco were collected in 2019/2020 from the Poland Tobacco Industrial Corporation and sent to laboratories for physicochemical property analysis. The ultimate analysis of tobacco was performed by using a Vario EL Cube elemental analyzer (Elementar Analysensysteme $\mathrm{GmbH}$, Langenselbold, Germany) and fractional analysis, using a thermogravimetric analyzer (TGA/SDTA851 LF, Mettler-Toledo, Greifensee, Switzerland). The results are presented in Table 1.

\subsection{Methods and Experiments}

\subsubsection{Properties of Tobacco}

Knowledge of the drying properties of tobacco and its dust is critical in designing a superheated steam dryer and optimizing production costs $[9,10]$. In the present work, tobacco properties were obtained and incorporated in the proposed model of an expanding 
superheated steam flash dryer. Furthermore, the explosion and fire properties of dust tobacco were determined by using a $20 \mathrm{~L}$ spherical explosion chamber, hot plate apparatus, Hartmann tube apparatus, and Godbert-Greenwald furnace apparatus.

Table 1. Chemical and physical composition of the tobacco (wt.- $\%$, dry basis).

\begin{tabular}{ccccccc}
\hline Sample & $\mathbf{C}$ & $\mathbf{H}$ & $\mathbf{N}$ & $\mathbf{S}$ & $\mathbf{O}^{*}$ \\
\hline \multirow{3}{*}{ Tobacco } & $36.69 \pm 0.12$ & $5.68 \pm 0.04$ & $2.90 \pm 0.02$ & $0.28 \pm 0.02$ & 54.45 \\
\cline { 2 - 7 } & Total moisture & Volatiles & Fived carbon & Ash & HHV (MJ/kg) \\
& $20.10 \pm 0.12$ & $56.90 \pm 0.35$ & $11.90 \pm 0.21$ & $11.10 \pm 0.11$ & 14.30 & \\
\hline
\end{tabular}

* Calculated by difference.

\subsubsection{Sorption Isotherms and Isobars}

Water in plant tissue may exist in two forms: bound water and unbound water. Water is considered bound when its partial pressure is lower than the saturated pressure of pure water. The ratio of partial pressure of water over tobacco $(p)$ to saturated water pressure $\left(p_{s}\right)$ at the same temperature (approximately) is called water activity, $a_{w}$, and is described in Equation (1).

$$
a_{w}=\frac{p}{p_{s}}
$$

The dependence of water activity on moisture content $b$ (in \%) or X (in $\mathrm{kg}$ of water $/ \mathrm{kg}$ dry mass) at constant temperature is called a sorption isotherm. A sorption isotherm represents the thermodynamic equilibrium between the wet solid and humid air and is indispensable for calculating rehumidification, storage, drying, and other processes involving moist air and tobacco. The sorption isotherm can be obtained experimentally by several methods, of which conditioning tobacco samples' oversaturated solutions of various salts is the simplest and cheapest of all. By changing salt solutions, the partial pressure of water in the air is controlled at a constant temperature. The experimental data are obtained either by starting with a wet solid and gradually lowering the moisture content (desorption isotherms) or by measuring moisture uptake of a previously dried solid (sorption isotherm). The two may not be identical, and certain sorption hysteresis almost always exists. In general, sorption isotherms have the shape of a learning curve (S-shape) and can be described by one of several dozens of empirical or semi-empirical equations. Ono and Yoshida [11] obtained the following equations for sorption isotherms of tobacco.

For flue-cured tobacco:

$$
X_{e}=0.2135 \exp \left(-0.9043 \cdot 10^{-6} \cdot R \cdot \frac{1000}{M} \cdot T \cdot \ln \left(\frac{1}{a_{w}}\right)\right)+0.4766 \exp \left(-3.92 \cdot 10^{-5} \cdot R \cdot \frac{1000}{M} \cdot T \cdot \ln \left(\frac{1}{a_{w}}\right)\right)
$$

For air-cured tobacco:

$$
X_{e}=0.1014 \exp \left(-3.119 \cdot 10^{-6} \cdot R \cdot \frac{1000}{M} \cdot T \cdot \ln \left(\frac{1}{a_{w}}\right)\right)+0.399 \exp \left(-3.591 \cdot 10^{-5} \cdot R \cdot \frac{1000}{M} \cdot T \cdot \ln \left(\frac{1}{a_{w}}\right)\right)
$$

These equations are valid for temperatures up to $80{ }^{\circ} \mathrm{C}$. For green Virginia-type tobacco, Kiranoudis et al. [12] recommended Equation (4).

$$
X_{e}=\frac{2.62}{(T-273)\left(1-a_{w}\right)^{0.637}}-3.05 \cdot 10^{-4} \cdot(T-273) \cdot a_{w}
$$

Legros et al. [13] derived Equation (5) based on cut lamina obtained from the BAT company for blend 72 in the range of 20 to $60{ }^{\circ} \mathrm{C}$.

$$
a_{w}=\frac{1}{\exp (\exp (-0.652 \cdot \ln (X)-1.95))}
$$


The above equations are plotted in Figure 1, and they are compared with experimental results obtained by Miyauchi et al. [14] for bright yellow and Burley tobaccos.

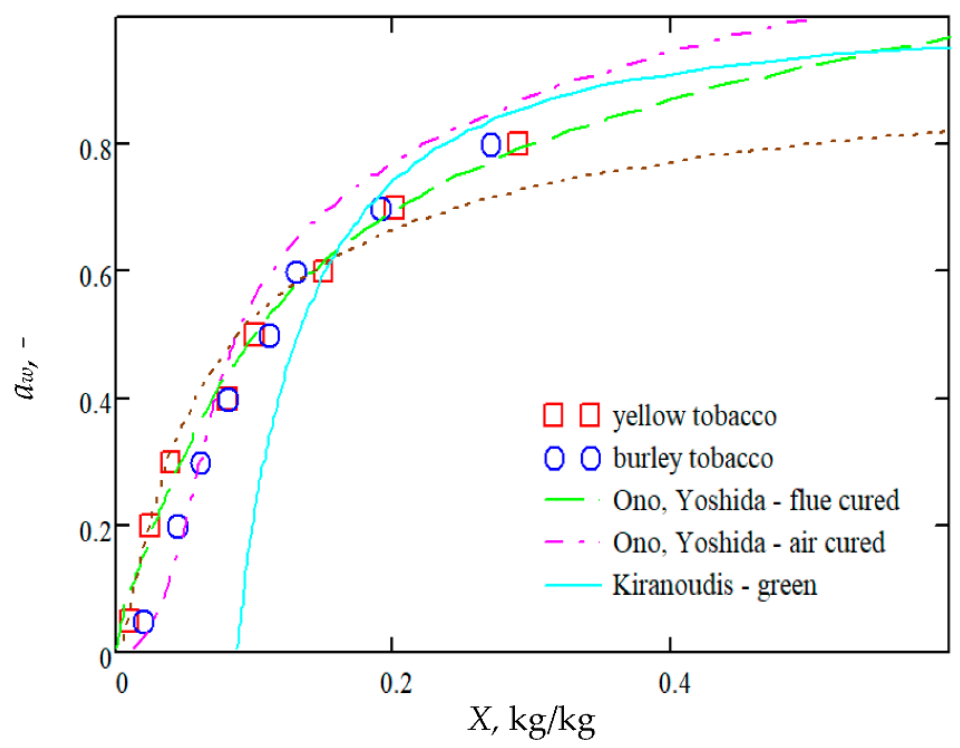

Figure 1. Comparison of experimental data obtained by References [11,12] and several empirical sorption isotherm equations for tobacco.

In superheated steam-drying, there is no inert gas (air) present in the system, so water activity is defined as the ratio of actual water pressure (ambient pressure) to the saturated pressure of pure water at a given temperature. Since the measurements are made at constant ambient pressure, the curves obtained are called sorption isobars. By changing temperature, the saturated pressure of water is controlled at constant pressure. The measurements of sorption isobars require a more sophisticated setup, especially when operating pressure is different than atmospheric pressure. The sorption isobars of tobacco were investigated in a setup built at the Lodz University of Technology (Poland), as shown in Figure 2. A detailed description of the apparatus and test procedure was presented in our previous publication [15].

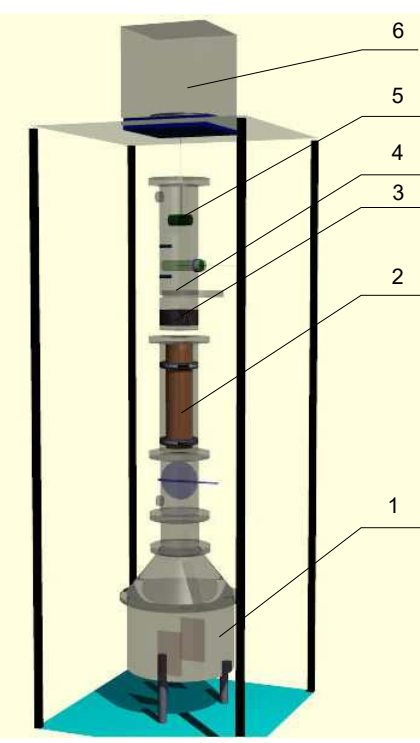

Figure 2. Schema of a setup for sorption isobar measurement at atmospheric pressure built at Lodz University of Technology [15]: 1-boiler, 2-superheater, 3-calming section, 4-steam temperature measurement, 5-sample, and 6-balance. 
Sorption isobars are traditionally presented to mean moisture content dependent on temperature. Exemplary sorption isobars for tobacco lamina and stem measured in this setup are shown in Figure 3.

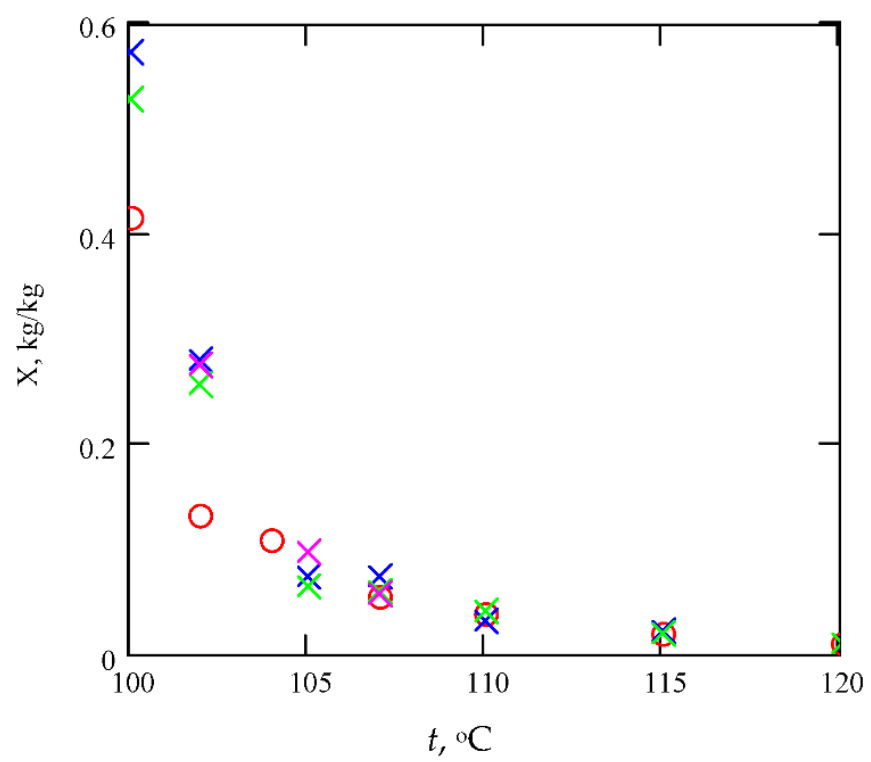

Figure 3. Sorption isobars for cut tobacco lamina (x) and stem (o).

Again, sorption isobars may be approximated by a selected empirical equation. However, one may consider replotting Figure 3 as $a_{w}=f(X)$, defining $a_{w}$ by the following equation.

$$
a_{w}=\frac{P_{0}}{p_{s}(t)}
$$

The curve obtained is shown in Figure 4 for lamina only.

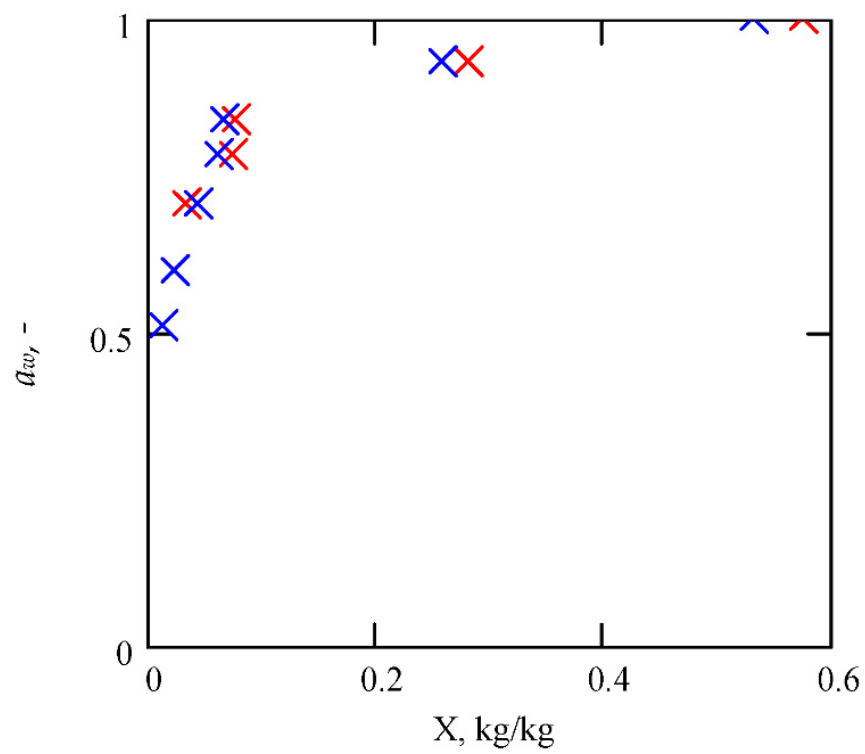

Figure 4. Data from Figure 3 replotted in $a_{w}$ vs. X coordinates (lamina only).

The curve that can be fitted to the points of Figure 4 is not an isotherm, since the points are obtained at varying temperatures, but an isobar. Adding a third axis, i.e., temperature, would allow the data of sorption isotherms and sorption isobars to be shown simultaneously. Such a 3D chart can be thought of as a generalization of sorptional equilibrium over a wide temperature and moisture-content range [16] that can be represented as a 3D 
surface that can be fitted with a suitable empirical equation. Such an empirical equation by Chen and Clayton [17] was fitted to scarce data available for tobacco, and the result is shown in Figure 5.

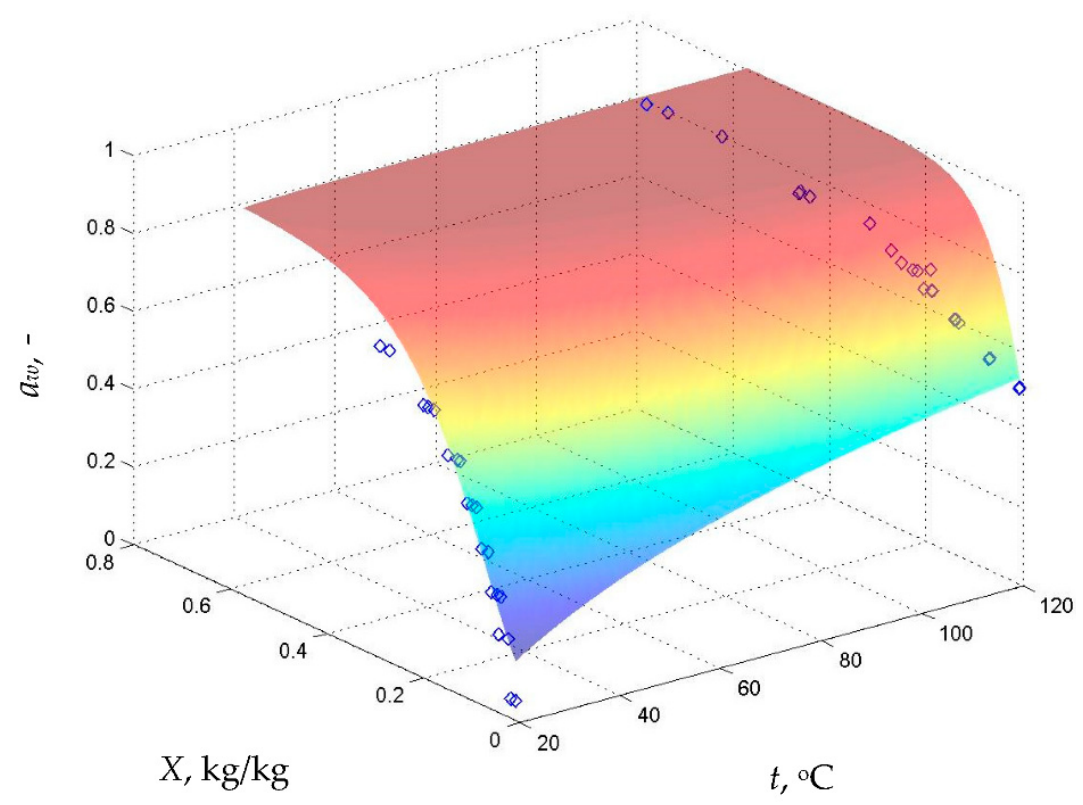

Figure 5. Three-dimensional sorption-equilibrium equation fitted to our experimental results (blue dots).

The equation has the following form:

$$
a_{w}=\exp \left[a_{1} t^{a_{2}} \exp \left(a_{3} t^{a_{4}} X\right)\right]
$$

where $a_{1}=-10.593, a_{2}=-0.54254, a_{3}=-2.9855$, and $a_{4}=0.3993$.

It is obvious that producing a more reliable equation would require a substantial experimental effort. It may be added that having in mind the three types of drying processes mentioned in the introduction, each one would require its sorption equilibrium to be measured individually. It is well-known that green tissue has different sorptional properties than rehydrated tissue. Similarly, adding sauces that contain soluble components can significantly alter the sorptional properties making tobacco more hygroscopic. Differences between tobacco cultivars in terms of sorptional equilibrium are less pronounced than differences between lamina and stem. Apparently, it is the cell morphology that decides water activity. Further studies to support this thesis are needed.

- Heat capacity of tobacco:

The heat capacity of tobacco is necessary for the calculation of solid temperature in the falling drying rate period. It can be measured in a scanning calorimeter as a function of temperature. The specific heat of dry tobacco was measured by a scanning calorimeter in a range of $25-140{ }^{\circ} \mathrm{C}$ by Pakowski et al. [4] and an average value of $1.467 \mathrm{~kJ} / \mathrm{kgK}$ was adopted. Kerekes et al. [18] quotes a slightly smaller value of $1.382 \mathrm{~kJ} / \mathrm{kg} \mathrm{K}$ obtained during air-curing of a Hungarian tobacco variety.

- Particle morphology and drag coefficient:

Cut tobacco has the form of thin ribbons, which are extremely difficult to describe. In pneumatic transport, the force of resistance to air flow of a single particle can be described in Equation (8).

$$
F_{D}=c_{D} \frac{u_{r}^{2}}{2} \rho_{g} S_{p}
$$

where $C_{D}$ is the drag coefficient, $u_{\mathrm{r}}=u_{g}-u_{m}$ is the velocity difference of solid and air, and $S_{p}$ is the cross-section area perpendicular to flow. Formulas for the drag coefficient depend 
on particle morphology. For isometric particles (those having all three basic dimensions of the same order of magnitude), the following formula of Haider and Levenspiel [19] is recommended.

$$
\begin{gathered}
c_{D}=\frac{24}{\operatorname{Re}}\left[1+\exp \left(2.3288-6.4581 \psi+2.4486 \psi^{2}\right) \operatorname{Re}^{0.0964+0.5565 \psi}\right]+ \\
+\frac{\operatorname{Re} \cdot \exp \left(4.905-13.8944 \psi+18.4222 \psi^{2}-10.2599 \psi^{3}\right)}{\operatorname{Re} \cdot \exp \left(1.4681+12.2584 \psi-20.7322 \psi^{2}+15.8855 \psi^{3}\right)}
\end{gathered}
$$

where

$$
\begin{gathered}
\operatorname{Re}=\frac{\left|u_{g}-u_{m}\right| d_{p} \rho_{g}}{\mu_{g}} \\
\psi=\frac{\text { surface area of equivalent sphere }}{\text { particle area }}
\end{gathered}
$$

In a single-particle model of pneumatic transport, it is necessary to represent the solid phase by individual monodisperse particles. Despite inherent difficulties in describing the morphology of cut tobacco [20], we found out that for the purpose of our model the combination of equivalent particle diameter, $d_{p}$, of $1.2 \mathrm{~mm}$ and sphericity $\psi$ of 0.15 together with a particle density of $800 \mathrm{~kg} / \mathrm{m}^{3}$ works well and gives good simulation results.

- Explosion and fire properties of dust tobacco:

Explosion and fire properties of tobacco after drying with superheated steam, such as maximum explosion pressure, $P_{\max }$; maximum rate of pressure rise, $(d P / d t)_{\max }$; explosion index, $K_{S t}$; minimum explosion concentration, $M E C$; minimum ignition energy, MIE; minimum ignition temperature, MIT; and limiting oxygen concentration, LOC [6,7], were experimentally determined according to standards shown in Table 2.

Table 2. Standards used to determine of explosion and fire properties of tobacco.

\begin{tabular}{ccc}
\hline Parameter & Unit & Standard \\
\hline$P_{\max }$ & $\mathrm{bar}$ & EN 14034-1 \\
$(d P / d t)_{\max }$ & $\mathrm{bar} / \mathrm{s}$ & EN 14034-2 \\
$K_{\text {stmax }}$ & $((\mathrm{bar} \cdot \mathrm{m}) / \mathrm{s})$ & EN 14034-2 \\
$M E C$ & $\mathrm{~g} / \mathrm{m}^{3}$ & EN 14034-3, ISO/IEC 80079-20-2 \\
$L O C$ & volume $\%$ & EN 14034-4 \\
$M I T_{5 \mathrm{~mm}}$ & ${ }^{\circ} \mathrm{C}$ & EN 50281-2-1, ISO/IEC 80079-20-2 (method CTHP) \\
$M I T_{50 \mathrm{~mm}}$ & ${ }^{\circ} \mathrm{C}$ & EN 50281-2-1, ISO/IEC 80079-20-2 (method CTHP) \\
$M I T_{5 \mathrm{~mm}}$ & ${ }^{\circ} \mathrm{C}$ & (non-standard method CRHG) \\
$M I T_{50 \mathrm{~mm}}$ & ${ }^{\circ} \mathrm{C}$ & (non-standard method CRHG) \\
$T c l$ & ${ }^{\circ} \mathrm{C}$ & EN 50281-2-1, ISO/IEC 80079-20-2 \\
$M I E$ & $\mathrm{~mJ}$ & EN 13821, ISO/IEC 80079-20-2 \\
\hline
\end{tabular}

Samples of tobacco were milled with a vibration laboratory mill (LMW, Testchem, Pszów, Poland), and powder with a grain size lower than $500 \mu \mathrm{m}$ was chosen for the experiments. An IPS particle size analyzer (Kamika Instruments, Warsaw, Poland) was used to evaluate the particle size distribution. The Sauter mean diameters of the tobacco dust particles were $86.7 \mu \mathrm{m}$. Such sizes of tobacco dust can deposit on device surfaces and pose potential fire and explosion hazards.

A standard 20 L dust-explosion vessel (SPD-2.2, ANKO, Warsaw, Poland) with a dispersion, vacuum, pressure sensor, ignition, control, and data-acquisition system, as shown in Figure 6, was applied to estimate $P_{\max },(d P / d t)_{\max }, K_{\mathrm{St}}, L O C$, and MEC. The tobacco dust was loaded in a $0.6 \mathrm{~L}$ reservoir, premixed with pressurized air $(20 \mathrm{bar})$, and then dispersed into the vessel through the fast-acting valve and ignited after $60 \mathrm{~ms}$. Two pyrotechnical igniters (Fr. Sobbe GmbH, Dortmund, Germany) with ignition energy each of $1 \mathrm{~kJ}$ were used to measure MEC and LOC, and of $5 \mathrm{~kJ}$ to evaluate $P_{\max }$ and $(d P / d t)_{\max }$. Tests in the $20 \mathrm{~L}$ dust-explosion vessel were conducted by systematically increasing the dust concentration from 125 to $1500 \mathrm{~g} / \mathrm{m}^{3}$, until $P_{\text {ex }}$ and $(d P / d t)_{\text {ex }}$ results reached a maximum 
value $\left(P_{\max },(d P / d t)_{\max }\right)$. In the case of $M E C$, three measurement series were made, starting with a $500 \mathrm{~g} / \mathrm{m}^{3}$ concentration, followed by 250,125 , and $60 \mathrm{~g} / \mathrm{m}^{3}$.

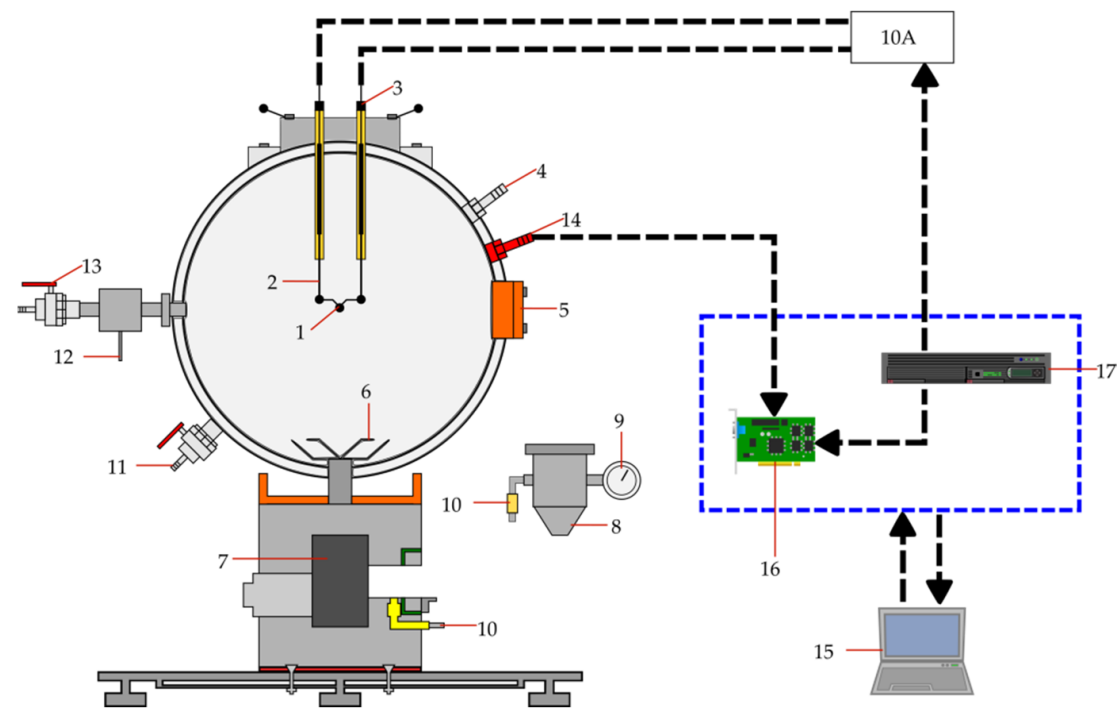

Figure 6. Scheme of standard $20 \mathrm{~L}$ dust-explosion vessel [7]: (1) chemical igniter, (2) electrode, (3) ignition leads, (4) water inlet, (5) inspection window, (6) nozzle, (7) fast-acting valve, (8) dust chamber, (9) pressure gauge, (10) pressure line, (11) water outlet, (12) vacuumized line, (13) exhaust valve, (14) pressure sensor, (15) PC, (16) data-acquisition card, and (17) time controller.

The minimum ignition temperature of the tobacco dust cloud was determined by using the equipment presented in Figure 7. The central part of the Godbert-Greenwald furnace (MAIT/MIT, Anko, Warsaw, Poland) was an open-bottom silica tube with a diameter of $3.9 \mathrm{~cm}$ and a height of $23 \mathrm{~cm}$. This tube was heated to the desired temperature with a device that controls the temperature of the furnace [21]. The tests confirmed that the temperature distribution of the furnace tube was homogeneous. During each experiment, compressed air was introduced into the tube at pressures of $10,20,30$, and $50 \mathrm{kPa}$ to create a dust cloud. Tobacco dust loads in measurements of $0.1,0.2$, and $0.3 \mathrm{~g}$, and $0.5 \mathrm{~g}$ were used. The first measurement was made at $500{ }^{\circ} \mathrm{C}$, a weight of $0.3 \mathrm{~g}$, and pressure of blown air of $30 \mathrm{kPa}$. The dust mass of tobacco at which the highest flame intensity was observed was determined.

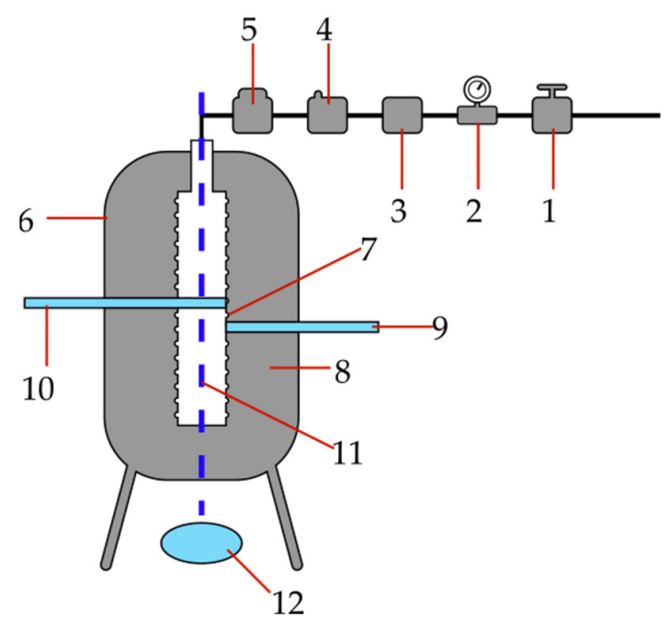

Figure 7. Scheme of measurement equipment for minimum ignition temperature of a tobacco dust cloud [7]: (1) stopstock, (2) pressure gauge, (3) pressure vessel, (4) electromagnetic valve, (5) dustsample container, (6) furnace shell, (7) heating, (8) thermal insulation materials, $(9,10)$ thermocouples, (11) quartz furnace tube, and (12) reflector. 
The Hartmann tube equipment (MINOR 2, ANKO, Warsaw, Poland) depicted in Figure 8 was applied to determine the minimum ignition energy of the tobacco dust-air mixture. The equipment was composed of a spark-generating circuit $(1 \mathrm{mH}$ and $1 \mu \mathrm{H})$, a glass tube with a pneumatic dust dispersion system, and a control panel that allowed the delay time to be set from 0 to $10,000 \mathrm{~ms}( \pm 10 \mathrm{~ms})$ and regulated the discharge spark energy from 1 to $1000 \mathrm{~mJ}$ [22]. In MIE, eleven measurement series were performed, starting with a $125 \mathrm{~g} / \mathrm{m}^{3}$ concentration and ending with $3000 \mathrm{~g} / \mathrm{m}^{3}$.

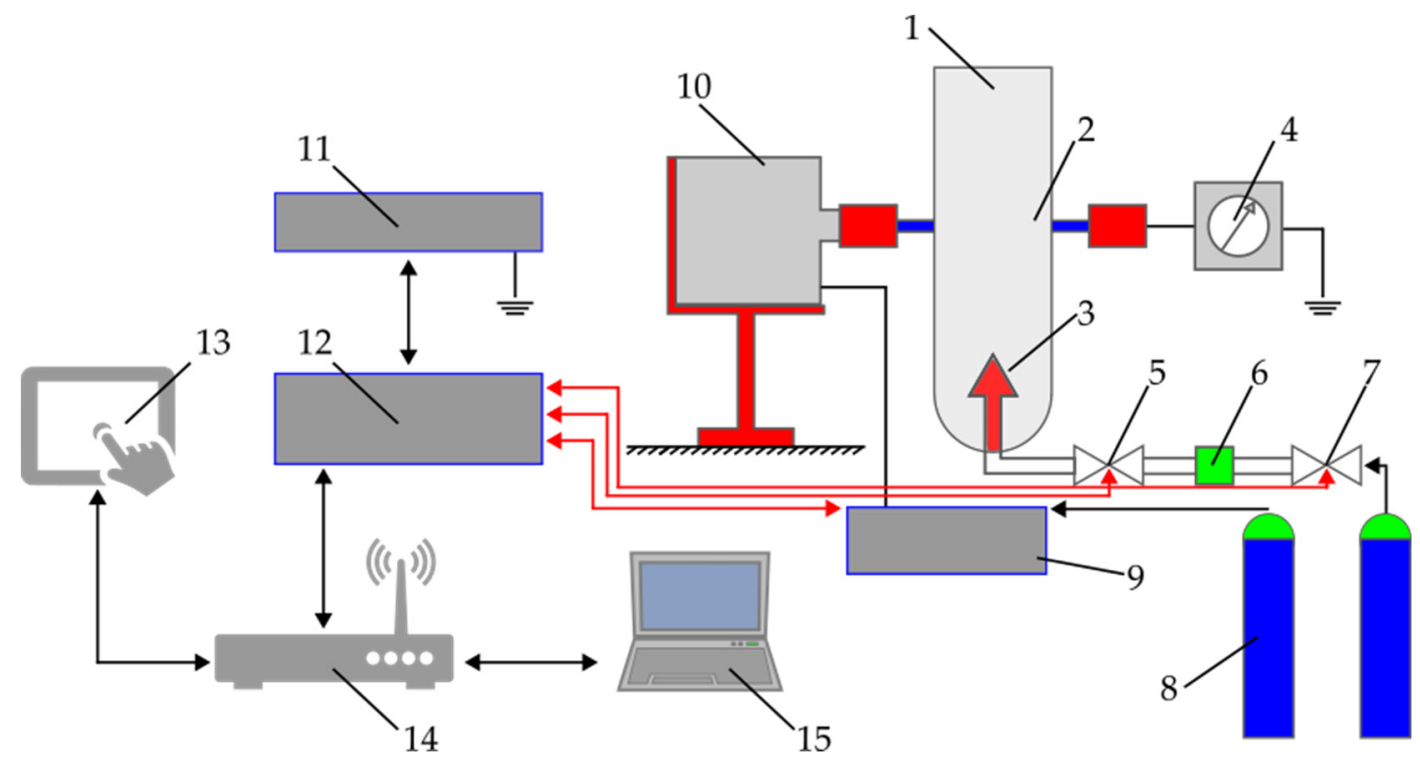

Figure 8. Scheme of Hartmann equipment [7]: (1) Hartmann tube, (2) electrodes, (3) nozzle, (4) micrometer, (5) outlet valve, (6) air reservoir, (7) inlet valve, (8) compressed air supply, (9) piston driver, (10) piston, (11) spark generator, (12) programmable logic controller, (13) human interface, (14) router, and (15) computer.

The measuring station of the hot plate (LIT-3, ANKO TRADING, Warsaw, Poland) presented in Figure 9 was used to determine the minimum ignition temperatures at which a layer of tobacco dust with the thickness of 5 and $50 \mathrm{~mm}$ deposited on a hot plate at a constant temperature and ignited and/or thermally decomposed [23]. To indicate the minimum ignition temperatures of the tobacco dust layer, two methods were used: the constant temperature of the heated plate (CTHP) and the constant rate of heat generation of $3^{\circ} \mathrm{C} / \mathrm{min}(\mathrm{CRHG})$.

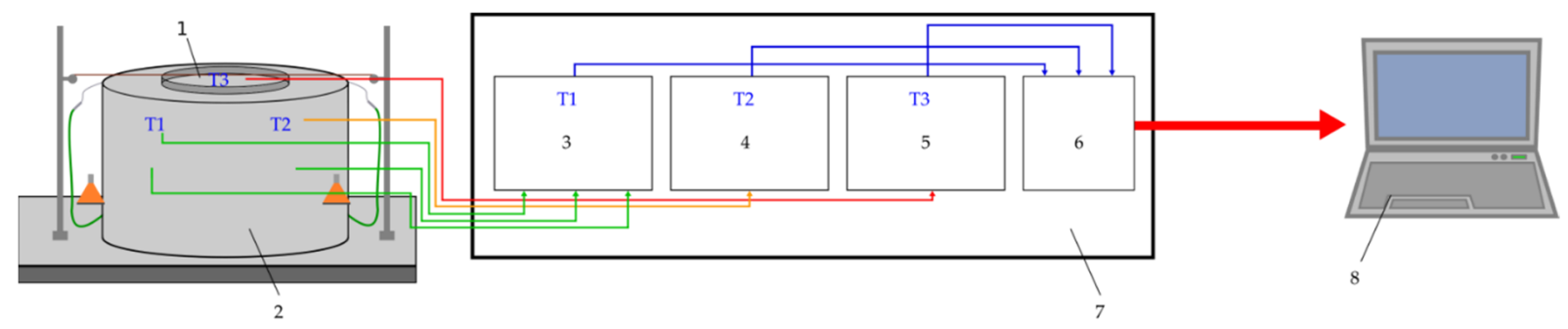

Figure 9. Scheme of measurement equipment for minimum ignition temperature of the tobacco dust layer [7]: (1) dust filling ring, (2) hot plate, (3-5) thermocouples, (6) USB PIC controller, (7) control and data-acquisition block, and (8) PC (personal computer).

\section{Principles of Superheated Steam-Drying}

When the steam is superheated, it can take in moisture from the wet solid until it becomes saturated. One part of the exiting steam can be superheated again and recycled into the dryer, while the other part is bled from the dryer and its heat can be recovered by condensation. This is, in short, a principle of superheated steam-drying. The idea was 
developed in Germany and was first mentioned in the literature in 1898 [20]. Although technically more difficult to accomplish than air-drying, superheated steam-drying has several advantages, which are shown below.

- Heat used for drying can be recovered thus lowering the net heat consumption even below the heat of vaporization.

- Solid temperature exceeds boiling point temperature: This effect causes the expansion of tobacco and sterilizes the product biologically.

- The atmosphere is virtually oxygen-free and thus oxidation reactions and danger of ignition are eliminated.

- Steam-drying is more effective than air-drying, provided that steam temperature is higher than the so-called inversion temperature (at atmospheric pressure the inversion temperature is ca. $175^{\circ} \mathrm{C}$ ).

The main disadvantages of superheated steam-drying are the following: materials undergoing drying must be temperature resistant, superheated steam is corrosive and requires better construction materials than air-drying, and thermal insulation must be good enough to prevent condensation on the walls $[4,7]$.

In convective air-drying, when evaporating free moisture, heat must be transferred through the boundary layer to the material and the resulting vapor must diffuse back through the boundary layer into the core of the air flow. Both processes limit the rate of drying. In superheated steam-drying, there is no diffusion of vapor through the gas phase, because the gas phase is pure vapor. Therefore, the drying rate of free moisture is entirely controlled by heat transfer.

When a wet solid is immersed into superheated steam, the following three periods can be observed.

Condensation period:

When the solid temperature is lower than the saturation temperature, steam condenses on the solid, and its temperature and moisture content increase. The drying rate in this period is negative and can be described as follows:

$$
\mathrm{w}_{\mathrm{D} 0}=-\frac{\alpha\left(\mathrm{t}_{\mathrm{s}}-\mathrm{t}_{\mathrm{m}}\right)}{\Delta \mathrm{h}_{\mathrm{v}}}
$$

Constant drying rate period:

After reaching the saturation temperature, free moisture is evaporated, and all heat transferred to the solid is used for moisture evaporation. This holds the solid temperature and the drying rate constant. The drying rate can be described by the following equation.

$$
\mathrm{w}_{\mathrm{DI}}=\frac{\alpha\left(\mathrm{t}_{\mathrm{g}}-\mathrm{t}_{\mathrm{s}}\right)}{\Delta \mathrm{h}_{\mathrm{v}}}
$$

Falling drying rate period:

When all free moisture is evaporated, the drying rate decreases. Now moisture must diffuse to the surface from the depths of the solid phase, and this slows the process down. In effect, the net heat transferred to the solid is only partly used for evaporation of moisture, and thus the temperature of the solid increases. In order to describe the drying rate in this period, a detailed model of water diffusion in the solid would be needed. Such models are complex and difficult to use in practice. Instead, a simple empirical model can be used where the drying rate is proportional to the portion of moisture content remaining in the solid according to the following equation.

$$
\mathrm{w}_{\text {DII }}=\frac{\alpha\left(\mathrm{t}_{\mathrm{g}}-\mathrm{t}_{\mathrm{m}}\right)}{\Delta \mathrm{h}_{\mathrm{v}}}\left(\frac{X-X_{\mathrm{eq}}}{X_{\mathrm{c}}-X_{\mathrm{eq}}}\right)^{\mathrm{n}}
$$

In this equation, $\mathrm{n}$ is an empirical parameter that can be evaluated on the basis of experimental data. If no information is available, $n=1$ is a good initial guess. Both critical 
moisture content, $X_{c}$, and equilibrium moisture content, $X_{e q}$, can be obtained from the sorption isobar.

A superheated steam flash dryer (CLED) is shown schematically in Figure 10. The drying pipe is the section between control points 0 and 1 . Wet tobacco is introduced through a rotating airlock into the pipe when it is carried away by steam flowing with a velocity of ca. $27-30 \mathrm{~m} / \mathrm{s}$. During its short residence in the pipe, the tobacco loses moisture and heats up. It is then separated from the steam in the cyclone and leaves the dryer through another airlock. The steam leaving the cyclone is partly vented and partly circulated by a circulating fan. It is then indirectly reheated in the superheater and returned to the dryer pipe.

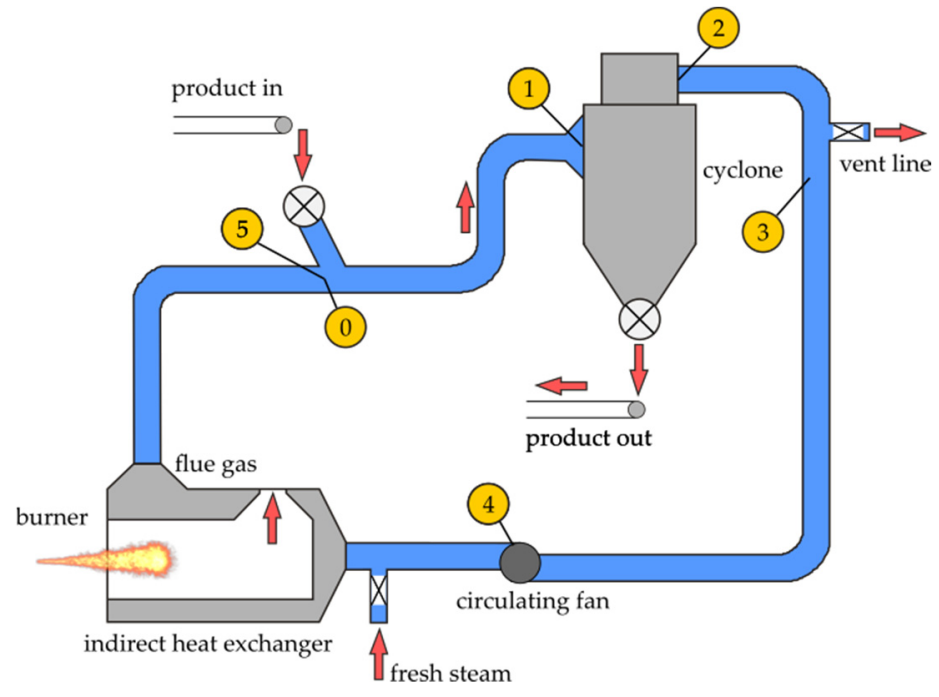

Figure 10. Schematic of a superheated steam flash dryer.

\section{Proposed Model of Superheated Steam Flash Drying of Cut Tobacco}

\subsection{Earlier Work}

Models for superheated-steam flash drying available vary in complexity from relatively simple (e.g., Reference [24]) to complex ones (e.g., Reference [25]). Generally, the solid is represented by monodisperse or polydisperse isotropic particles characterized by certain equivalent diameters (diameter of a sphere of equal volume) and sphericity (Equation (11)). In the case of polydisperse solids [24], the particle size range needs to be divided into seven fractions each, calculated separately. In this case, small particles may be already dry, while large particles are still in the heat-up period: it is also recommended that the heat transfer coefficient be adjusted for simultaneous mass transfer, using the correction shown below:

$$
\mathrm{Nu}_{\mathrm{ss}}=\mathrm{Nu}\left(\frac{\ln (1+\mathrm{B})}{\mathrm{B}}\right)
$$

where

$$
B=\frac{c_{g}\left(T_{g}-T_{s}\right)}{\Delta h_{v}}
$$

However, for temperatures of steam up to $300{ }^{\circ} \mathrm{C}$, at atmospheric pressure, this correction does not exceed $94 \%$ of the value for pure heat transfer, so it can be neglected in engineering calculations. A two-dimensional model of pneumatic transport used by Reference [25] is recommended for more accurate calculations: the degree of complexity associated with it makes the calculations too expensive for ordinary applications. Furthermore, the improved accuracy it brings may be offset by the inaccuracy of empirical coefficients used in the model.

Assumptions:

In flash-drying, dispersed tobacco particles are fed into superheated steam, flowing at a velocity of ca. $30 \mathrm{~m} / \mathrm{s}$, which is much higher than the entrainment velocity. The particles 
are carried away by steam in the dryer pipe when they undergo drying and expansion. Dry particles are separated in a cyclone. The process is complex, and its mathematical description must be considerably simplified in order to construct a model that can be solved. The following assumptions are made:

- The solid is represented by single isometric particles of the same size;

- The flow of the suspension is one-dimensional. That is to say, no radial distribution of velocity, temperature, and/or concentration in the pipe are allowed;

- A steady-state plant operation is assumed;

- Only the process of drying in the pipe is considered: drying in a cyclone would require another model.

\subsection{Model Formulation}

The steady-state one dimensional distributed parameter model of the flash dryer can be constructed by establishing the momentum, heat, and mass balances over a differential volume element of the pipe shown in Figure 11. The variables used in Section 4.2 are defined in the nomenclature section.

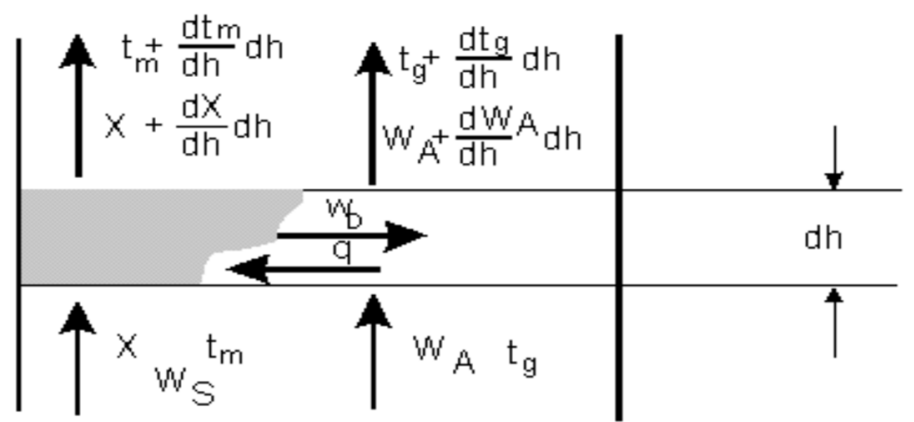

Figure 11. Schematic of the momentum, heat, and mass balances over a differential volume element of the dryer pipe.

The following balances can be written.

- Mass balance for the solid phase:

$$
W_{S} \frac{d X}{d h} d h=-w_{D} a_{V} S d h
$$

from which we have the following:

$$
\frac{d X}{d h}=-w_{D} a_{V} \frac{S}{W_{S}}
$$

- Enthalpy balance for the solid phase:

$$
W_{S} \frac{d i_{m}}{d h} d h=S d h\left(q-w_{D} h_{A v}\right) a_{V}
$$

where, by using enthalpy definitions, we have the following:

$$
\begin{gathered}
i_{m}=\left(c_{A l} X+c_{S}\right) t_{m}-\Delta h_{S} \\
h_{A}=c_{A} t_{m}+\Delta h_{v 0},
\end{gathered}
$$

we have the following:

$$
\left(c_{A l} X+c_{S}\right) \frac{d t_{m}}{d h}+c_{A l} t_{m} \frac{d X}{d h}=\frac{S}{W_{S}}\left[q-w_{D}\left(c_{A} t_{m}+\Delta h_{v 0}\right)\right] a_{V}
$$


Then, by using (20)-(21) and rearranging, we finally have the following:

$$
\frac{d t_{m}}{d h}=\frac{1}{c_{A l} X+c_{S}} \frac{S}{W_{S}}\left[q-w_{D}\left[\left(c_{A}-c_{A l}\right) t_{m}+\Delta h_{v 0}\right]\right] a_{V}
$$

- Mass balance for the gas phase:

$$
\frac{d W_{A}}{d h} d h=w_{D} a_{V} S d h
$$

since

$$
W_{A}=\rho_{g} \varepsilon u_{g} S
$$

Then, by combining (24) and (25), we have the following:

$$
\frac{d\left(\rho_{g} \varepsilon u_{g}\right)}{d h}=w_{D} a_{V}
$$

and

$$
\varepsilon u_{g} \frac{d \rho_{g}}{d h}+u_{g} \rho_{g} \frac{d \varepsilon}{d h}+\varepsilon \rho_{g} \frac{d u_{g}}{d h}=w_{D} a_{V}
$$

Introducing the ideal gas equation for calculation of gas density change with temperature,

$$
\frac{d \rho_{g}}{d h}=-\frac{P_{0} M_{A}}{R\left(t_{g}+t_{0}\right)^{2}} \frac{d t_{g}}{d h},
$$

we finally have the following:

$$
\frac{d u_{g}}{d h}=\frac{1}{\varepsilon \rho_{g}}\left[\varepsilon u_{g} \frac{P_{0} M_{A}}{R\left(t_{g}+t_{0}\right)^{2}} \frac{d t_{g}}{d h}-u_{g} \rho_{g} \frac{d \varepsilon}{d h}+w_{D} a_{V}\right]
$$

- Enthalpy balance for gas phase:

$$
\frac{d\left(W_{A} i_{g}\right)}{d h} d h=-S d h\left(q-w_{D} h_{A v}\right) a_{V}
$$

Since the gas phase is pure steam,

$$
i_{g}=h_{A v}=c_{A} t_{g}+\Delta h_{v 0},
$$

by introducing into (23) and rearranging, we have the following:

$$
\frac{d t_{g}}{d h}=-\frac{S}{W_{A} c_{A}}\left[q-w_{D}\left(c_{A} t_{m}-c_{A} t_{g}\right)\right] a_{V}
$$

Now, to be able to calculate changes of solid velocity and voidage with height, two additional equations must be introduced.

- The continuity equation for the solid phase:

$$
\rho_{m}(1-\varepsilon) u_{m}=\text { const }
$$

therefore

$$
\frac{d\left[\rho_{m}(1-\varepsilon) u_{m}\right]}{d h}=0
$$

Then, after differentiation and separation of terms, we have the following:

$$
\frac{d \varepsilon}{d h}=\frac{1-\varepsilon}{\rho_{m} u_{m}}\left(u_{m} \frac{d \rho_{m}}{d h}+\rho_{m} \frac{d u_{m}}{d h}\right)
$$


- Kinetic energy balance for the solid phase:

$$
\frac{d\left[\rho_{m}(1-\varepsilon) u_{m}^{2}\right]}{d h}=F_{D}-\left(\rho_{m}-\rho_{g}\right)(1-\varepsilon) g
$$

Now, by differentiation, we have the following:

$$
u_{m} \frac{d\left[\rho_{m}(1-\varepsilon) u_{m}\right]}{d h}+\rho_{m}(1-\varepsilon) u_{m} \frac{d u_{m}}{d h}=F_{D}-\left(\rho_{m}-\rho_{g}\right)(1-\varepsilon) g
$$

Since the first term is zero, we have the following:

$$
\frac{d u_{m}}{d h}=\frac{1}{u_{m}}\left[\frac{F_{D}}{\rho_{m}(1-\varepsilon)}-\frac{\rho_{m}-\rho_{g}}{\rho_{m}} g\right]
$$

The drag force can be calculated from numerous theories. One often used reads as follows:

$$
F_{D}=\frac{3}{4} c_{D} \rho_{g} \frac{\left(u_{g}-u_{m}\right)^{2}}{d_{p}}(1-\varepsilon) \varepsilon^{-2.68}
$$

Finally, the kinetic energy balance takes the following form:

$$
\frac{d u_{m}}{d h}=\frac{1}{u_{m}}\left[\frac{3}{4} c_{D} \frac{\rho_{g}}{\rho_{m}} \frac{\left(u_{g}-u_{m}\right)^{2}}{d_{p}} \varepsilon^{-2.68}-\frac{\rho_{m}-\rho_{g}}{\rho_{m}} g\right]
$$

The momentum balance equation for the gas phase can be used for the calculation of pressure drop along the dryer pipe:

$$
\frac{d p}{d z}=-\left[c_{D g w} \rho_{g} \frac{u_{g}^{2}}{2 D}+c_{V} \rho_{m}\left(\frac{\rho_{m}-\rho_{g}}{\rho_{m}} g+c_{D p w} \frac{u_{g}^{2}}{2 D}+u_{m} \frac{d u_{m}}{d z}\right)\right]
$$

The above-framed relationships form a one-dimensional model of flash drying with superheated steam. For the calculation of several variables involved in this formulation, constitutive- and property-defining equations are necessary. The following relationships are used.

- Sensible heat flux:

The sensible heat flux, $q$, is calculated as follows:

$$
q=\alpha\left(t_{g}-t_{m}\right)
$$

where $\alpha$ is the heat transfer coefficient. Numerous correlations exist for the calculation of heat transfer coefficients in pneumatic transport. For the purpose of this model, the following equations of Bandrowski and Kaczmarzyk [17] were selected.

For $u_{g}-u_{m}<1.2 u_{t}$, we have the following:

$$
N u=0.00114 c_{V}{ }^{-0.5984} \operatorname{Re}^{0.8159}
$$

For $u_{g}-u_{m} \geq 1.2 u_{t}$, we have the following:

$$
N u=(0.00114+0.0094 f) c_{V}^{-0.5911} \operatorname{Re}^{0.8159-0.3159 f}
$$

where

$$
\begin{gathered}
f=\sqrt{1-\frac{u_{t}}{u_{g}-u_{m}}} \\
c_{V}=\frac{1-\varepsilon}{\varepsilon}
\end{gathered}
$$


- Drying rate:

Drying rate equations were defined earlier as Equations (7) through (9).

- Transport velocity:

The following formula of Goroshko et al. [19] was used.

$$
\operatorname{Re}_{t}=\frac{A r}{18+0.61 \sqrt{A r}}
$$

where

$$
A r=\frac{d_{p}^{3} \rho_{g} g\left(\rho_{m}-\rho_{g}\right)}{\mu_{g}^{2}}
$$

- $\quad$ Voidage:

$$
\varepsilon=1-\frac{W_{S}(1+X)}{\rho_{m} S u_{m}}
$$

- Friction factors:

The gas-wall friction factor can be calculated from the following formula by Reference [26].

$$
c_{D g w}=0.0052+\frac{0.5}{\operatorname{Re}_{D} 0.32} \quad \text { for } 3000<\operatorname{Re}_{D}<3 \cdot 10^{6}
$$

where $\operatorname{Re}_{D}$ is the Reynolds number based on ductwork diameter.

The particle-wall friction factor in pneumatic transport was studied by Reference [27], and the following formulas were obtained.

For the acceleration zone, we have the following:

$$
c_{D p w}=0.0126 \frac{1-\varepsilon}{\varepsilon^{3}}\left[\frac{(1-\varepsilon) u_{t}}{u_{g}-u_{m}}\right]^{-0.979}
$$

Outside the acceleration zone, we have the following:

$$
c_{D p w}=0.0410 \frac{1-\varepsilon}{\varepsilon^{3}}\left[\frac{(1-\varepsilon) u_{t}}{u_{g}-u_{m}}\right]^{-1.021}
$$

- $\quad$ Specific area of contact:

$$
a_{V}=6 \frac{c_{V}}{d_{p} \psi}
$$

\section{Results}

\subsection{Model Simulation}

The proposed model of superheated steam flash drying of cut tobacco is composed of seven ordinary differential equations (ODEs), 18, 23, 29, 32, 35, 40, and 41. Equations (42) through (53) provide necessary auxiliary variables. All necessary steam properties are calculated from suitable relationships $[28,29]$. The set of ODEs can be solved, provided that initial conditions are available. Since the dryer operates in a closed loop, the external heat and mass balances for other components of the loop must be calculated until the parameters of steam at control point 5 (Figure 10) are identical to those of point 0 . This requires several iterations. In our study, the model was solved by using Mathcad mathematical software, assuming the general capacity of tobacco drying in a flash dryer of 3 tons/hour. Typical results of the basic parameters of the tobacco drying in the function of the apparatus length are shown in Figures 12-14, while Table 3 gives the results of the simulation using a superheated steam flash pneumatic dryer. 


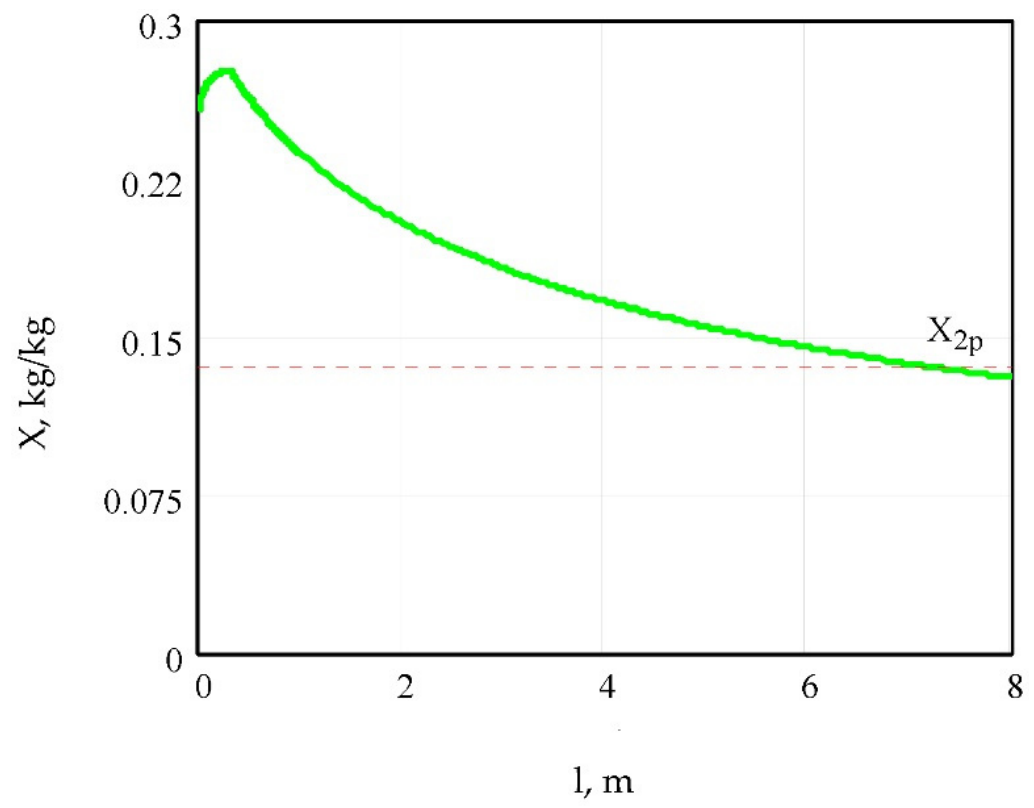

Figure 12. Moisture-content change in the function of the apparatus length.

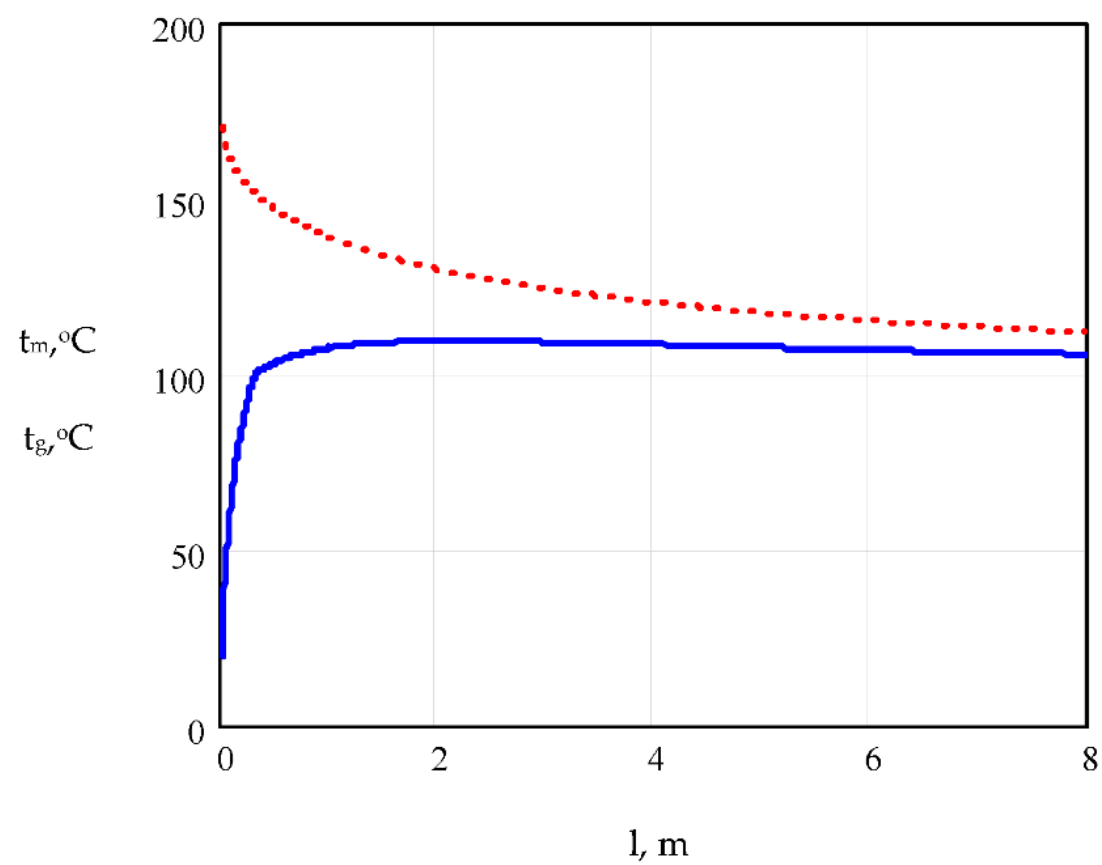

Figure 13. Steam temperature (dotted line) and tobacco temperature (solid line) in the function of the apparatus length.

Table 3. Results for a superheated steam pneumatic dryer of tobacco.

\begin{tabular}{cc}
\hline $\begin{array}{c}\text { Dimension and Parameters of Superheated } \\
\text { Steam Pneumatic Dryer }\end{array}$ & Results \\
\hline Length, $\mathrm{m}$ & 8.02 \\
Diameter, $\mathrm{m}$ & 0.5 \\
Dryer capacity, tons $/ \mathrm{h}$ & 3 \\
Inlet steam temperature, ${ }^{\circ} \mathrm{C}$ & 300 \\
Steam velocity, $\mathrm{m} / \mathrm{s}$ & 30 \\
Coefficient of heating medium excess, $\mathrm{kg} / \mathrm{kg}$ & 9 \\
Material dwell time, $\mathrm{s}$ & 0.4 \\
\hline
\end{tabular}




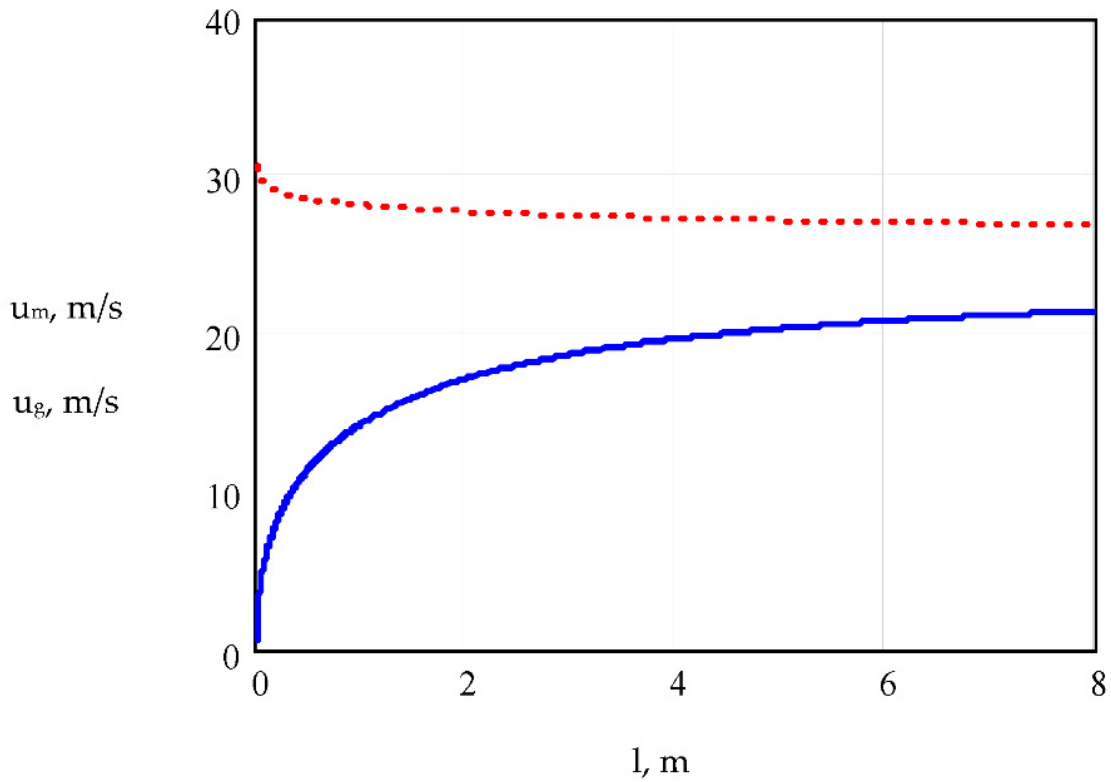

Figure 14. Steam velocity (dotted line) and tobacco velocity (solid line) in the function of the apparatus length.

\subsection{Fire and Explosion Properties of Tobacco}

The explosion and fire properties of tobacco before and after using the superheated steam-drying process at $160,170,180$, and $190{ }^{\circ} \mathrm{C}$ were experimentally investigated. The influence of the impact of drying conditions on the explosion sensitivity and severity parameters was noted, and it is shown in Table 4 and Figure 15. The results indicate that the higher the drying temperature, the more likely is the dust tobacco cloud to be ignited, the faster the explosion flame propagation, and the greater the explosion severity.

Table 4. Results of explosion and fire properties of tobacco.

\begin{tabular}{|c|c|c|c|c|c|c|}
\hline \multirow{2}{*}{ Parameter } & \multirow{2}{*}{ Unit } & \multirow{2}{*}{ Before Drying } & \multicolumn{4}{|c|}{ After Drying at Temperatures of } \\
\hline & & & $160^{\circ} \mathrm{C}$ & $170^{\circ} \mathrm{C}$ & $180^{\circ} \mathrm{C}$ & $190^{\circ} \mathrm{C}$ \\
\hline$P_{\max }$ & bar & $6.1 \pm 0.3$ & $6.3 \pm 0.3$ & $6.5 \pm 0.3$ & $6.6 \pm 0.3$ & $6.7 \pm 0.3$ \\
\hline$(d P / d t)_{\max }$ & $\mathrm{bar} / \mathrm{s}$ & $268 \pm 22$ & $321 \pm 34$ & $384 \pm 38$ & $399 \pm 36$ & $405 \pm 32$ \\
\hline$K_{\text {st } \max }$ & $(\mathrm{m} \cdot \mathrm{bar}) / \mathrm{s}$ & $72 \pm 12$ & $87 \pm 10$ & $104 \pm 11$ & $108 \pm 18$ & $109 \pm 14$ \\
\hline$M E C$ & $\mathrm{~g} / \mathrm{m}^{3}$ & $125 \pm 24.2$ & $60 \pm 11.2$ & $60 \pm 9.5$ & $60 \pm 9.1$ & $60 \pm 9.3$ \\
\hline LOC & $\% \mathrm{O}_{2}$ & 21 & 20 & 20 & 20 & 20 \\
\hline$M I T_{5 \mathrm{~mm}(\mathrm{CTHP})}$ & ${ }^{\circ} \mathrm{C}$ & $320 \pm 2.9$ & $310 \pm 2.6$ & $300 \pm 2.9$ & $290 \pm 2.8$ & $290 \pm 2.9$ \\
\hline $\mathrm{MIT}_{50 \mathrm{~mm}(\mathrm{CTHP})}$ & ${ }^{\circ} \mathrm{C}$ & $300 \pm 2.7$ & $280 \pm 2.9$ & $280 \pm 2.8$ & $270 \pm 2.9$ & $260 \pm 2.8$ \\
\hline$M I T_{5 \mathrm{~mm}(\mathrm{CRHG})}$ & ${ }^{\circ} \mathrm{C}$ & $280 \pm 2.9$ & $270 \pm 2.8$ & $270 \pm 3.6$ & $270 \pm 3.2$ & $260 \pm 3.2$ \\
\hline $\mathrm{MIT}_{50 \mathrm{~mm}(\mathrm{CRHG})}$ & ${ }^{\circ} \mathrm{C}$ & $290 \pm 4.3$ & $280 \pm 4.1$ & $270 \pm 3.8$ & $260 \pm 2.6$ & $250 \pm 3.8$ \\
\hline$T_{\mathrm{cl}}$ & $\mathrm{C}$ & $510 \pm 3.8$ & $440 \pm 2.6$ & $440 \pm 3.6$ & $440 \pm 2.6$ & $420 \pm 3.6$ \\
\hline MIE & $\mathrm{mJ}$ & & & MIE $>1000$ & & \\
\hline
\end{tabular}

Tobacco dust is of weak explosion class (St 1) [7]. Dust obtained by drying with superheated steam at $190{ }^{\circ} \mathrm{C}$ is characterized by the highest value of $K_{\text {stmax }}$, amounting to $109 \pm 14 \mathrm{~m} \cdot \mathrm{bar} \cdot \mathrm{s}^{-1}$, and the highest explosion pressure jump ( $\left.405 \pm 32 \mathrm{bar} / \mathrm{s}\right)$, as well as the maximum explosion pressure $(6.7 \pm 0.3 \mathrm{bar})$, which may cause the most significant damage during a potential event in premises where tobacco dust is dried with superheated steam, especially inside enclosed spaces. The value of the maximum pressure increase rate over time, $K_{\text {stmax }}$, was observed at the same dust concentration level at which the maximum explosion pressure values were estimated (Figure 15). 

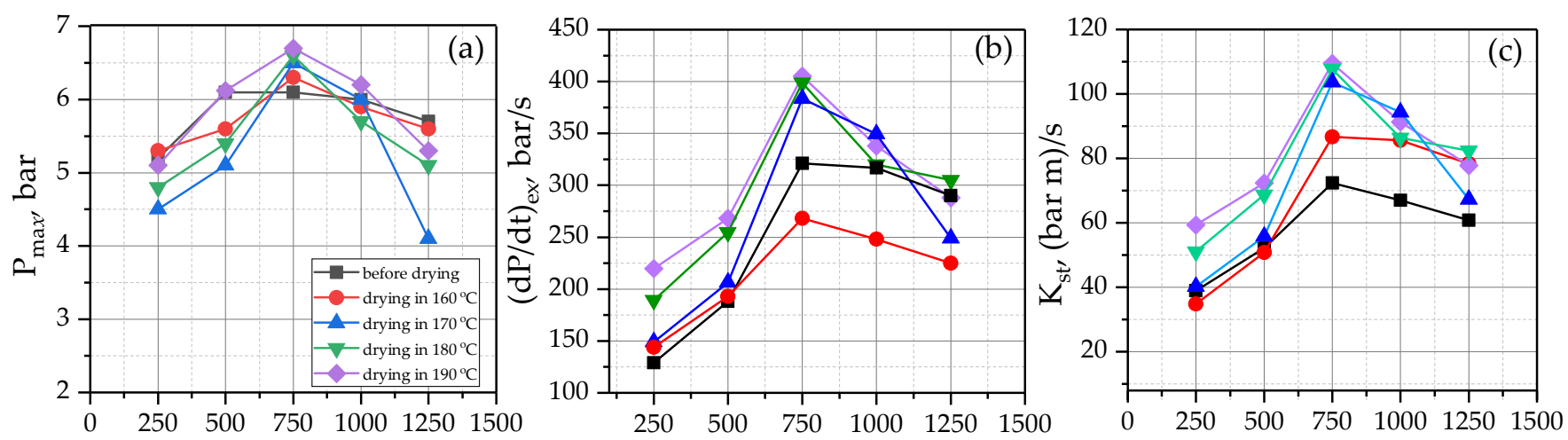

Nominal dust concentration, $\mathrm{g} / \mathrm{m}^{3} \quad$ Nominal dust concentration, $\mathrm{g} / \mathrm{m}^{3} \quad$ Nominal dust concentration, $\mathrm{g} / \mathrm{m}^{3}$

Figure 15. Impact of tobacco dust concentration on values of (a) $P_{\max },(\mathbf{b}) d P / d t_{\mathrm{ex}}$, and (c) $K_{\mathrm{st}}$.

Studies on the minimum explosive concentration revealed that the lowest concentration value for which tobacco dust before being dried with superheated steam may form an explosive atmosphere amounts to $125 \mathrm{~g} / \mathrm{m}^{3}$. The $M E C$ values of the dust after drying at $160,170,180$, and $190^{\circ} \mathrm{C}$ are lower, and the tobacco falls within the explosive range as soon as a concentration level of $60 \mathrm{~g} / \mathrm{m}^{3}$ is reached.

The MIE value of a tobacco cloud is indispensable for the assessment of fire and explosion hazards in a superheated-steam-drying system. According to the results summarized in Table 4, tobacco dust before and after drying is susceptible to ignition from the initials over $1000 \mathrm{~mJ}$. The MIE value identified in laboratory conditions can be lower in process conditions, since the air temperature during drying is higher. The probability of tobacco dust cloud ignition even in optimum conditions is low, as the ignition device energies used in experimental tests are much higher than the energy of authentic ignition sources. Dust explosion seems highly unlikely in factories where dust distribution is generally non-uniform, contrary to the test conditions. Despite many investigations, no single case of an explosion in tobacco factories has been discovered.

The minimum ignition temperature of tobacco dust, $T_{\mathrm{cl}}$, after superheated steamdrying at $190{ }^{\circ} \mathrm{C}$ is $90^{\circ} \mathrm{C}$ higher than the minimum ignition temperature of dust, which can be generated upon contact with non-thermally treated tobacco. It is caused by a higher moisture content in the material and reduced dust dispersion by increasing interparticle cohesion. The influence of the temperature of tobacco drying with superheated steam on the minimum ignition temperature of the tobacco-dust layer in contact with the surface is not so evident. For instance, the minimum ignition temperature value of dry tobacco dust, subject to tests, amounted to $M I T_{5 \mathrm{~mm}} 290{ }^{\circ} \mathrm{C} \pm 2.9$, while for tobacco dust before drying, the $M I T_{5 \mathrm{~mm}}$ at the heating-plate constant temperature amounted to $320^{\circ} \mathrm{C} \pm 2.9$. When analyzing the minimum ignition temperature, one should note that the MIT depends on the deposited-dust-layer thickness. Whenever the temperature was measured for a $50 \mathrm{~mm}$-thick layer, the MIT was on average $10-30{ }^{\circ} \mathrm{C}$ lower than the temperature for a $5 \mathrm{~mm}$-thick dust layer. The identification was also carried out at a constant rate of heat generation (CRHG method). In the standard CTHP method, the ignition is assumed to occur if the temperature in the dust layer exceeds the heating-plate temperature by at least $250{ }^{\circ} \mathrm{C}$. In the CRHG method, the heating-plate temperature changes during the measurements. In the reference case, the momentary temperature of the heating plate was taken into consideration by controlling the tobacco dust and heating-plate-temperature difference. For a $50 \mathrm{~mm}$-thick dust layer, the heating-plate temperature increased for the initial $40 \mathrm{~min}$ to become stable afterwards. Dust ignition in the thin layer occurred a long time before the heating-plate temperature became stable. A thicker dust layer reduces the MIT and extends the ignition time in the layer. The minimum ignition temperature value for tobacco dust after drying at $190{ }^{\circ} \mathrm{C}$, tested at a constant increase of the heating-plate temperature, amounted to $M I T_{5 \mathrm{~mm}} 260{ }^{\circ} \mathrm{C} \pm 3.2$, while for tobacco dust before drying, it was $280{ }^{\circ} \mathrm{C} \pm 2.9$. The differences become less significant as the dust layer thickness 
increases. For $50 \mathrm{~mm}$-thick layers, the differences stabilize at $10{ }^{\circ} \mathrm{C}$, which corresponds to the heating-plate-temperature rise when the CRHG method is used for its determination. The results reveal that in some cases, the standard method of a dust layer minimum ignition temperature determination may lead to hazard misestimation, whereby it may apply to the cases of the parameter determination for thick and thin dust layers. The maximum temperature for superheated-steam-drying equipment coated with an up to $5 \mathrm{~mm}$-thick tobacco layer should not exceed a temperature of $75^{\circ} \mathrm{C}$ lower than the dust layer minimum ignition temperature, amounting to $215^{\circ} \mathrm{C}$ in the reference case, according to the standard method, or $195^{\circ} \mathrm{C}$ based on the results according to the CRHG method. Based on experimental test results and previous experiments, it is recommended that general fire prevention measures be used. The drying process should be carried out in such a way that dustiness is avoided in the buildings. In order to reduce dust deposition, a cleaning procedure including cleaning at regular intervals should be followed including wet cleaning of equipment, or the equipment should be vacuumed with EX design devices meeting ATEX requirements for dust explosion hazard zones to avoid airborne dust [30,31]. Effective equipment maintenance systems, regular staff training on safety rules and fire regulations, observance of the regulations concerning hot work, and hot-work permits should be implemented.

\subsection{Validation of Results Obtained from the Proposed Model}

The superheated-steam-drying results of tobacco obtained from the proposed model were compared to experimental data summarized in Reference [4] that were obtained during test runs made by ITM on CLED installed in Minsk, Belarus, and performed in January and April 2001. Two types of cut tobacco blends were analyzed, T1 and T2, differing in their recipe. Twelve runs were performed in which the following parameters were measured: tobacco inlet and moisture content, steam inlet and outlet temperature, inlet tobacco flow rate, inlet steam flow rate, tobacco size distribution, and tobacco filling power before and after CLED. The inlet steam velocity occurred in a range of 27 to $30 \mathrm{~m} / \mathrm{s}$. Pipe diameter was $0.5 \mathrm{~m}$, and total pipe length, including horizontal section, vertical section, and two elbows, was $8.02 \mathrm{~m}$. In simulations, the value of empirical parameter $m$ in the kinetic equation for drying rate was taken as 0.4 . The experiments described above allow only for comparison of two parameters measured and simulated by the model, tobacco moisture content after dryer, and steam temperature at the pipe exit. The tobacco moisture content is best measured after the dryer pipe. Here, however, it was measured after the cyclone. The comparison of measured and simulated values is shown in Figures 16 and 17. The error-of-fit does not exceed several percents on average.

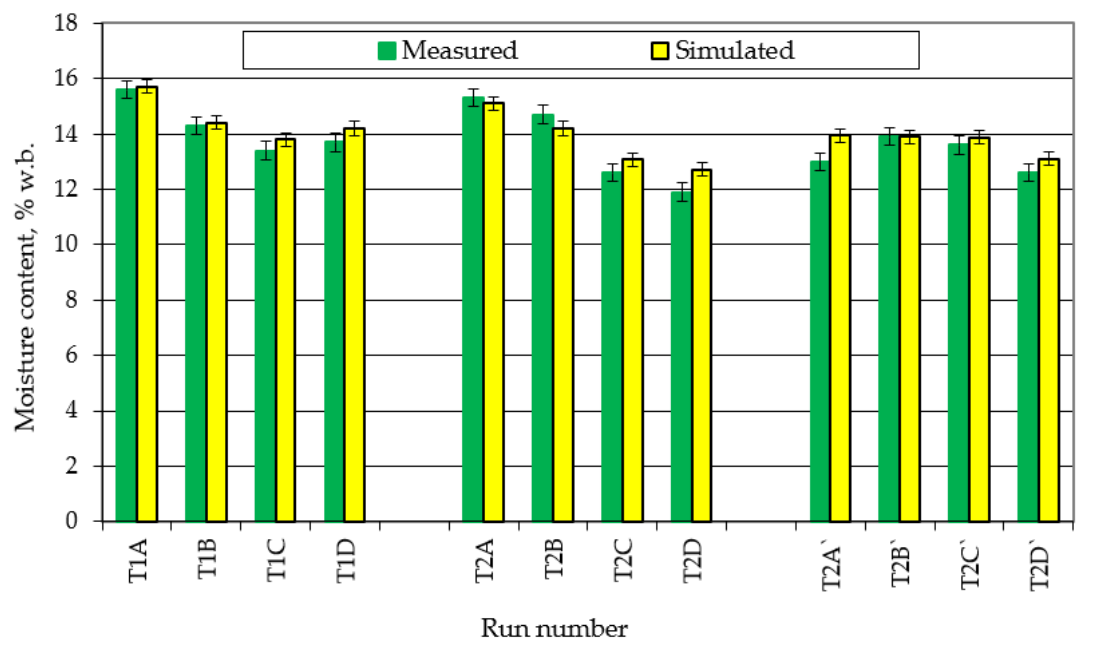

Figure 16. Results of experimental and modeling final tobacco moisture content. 


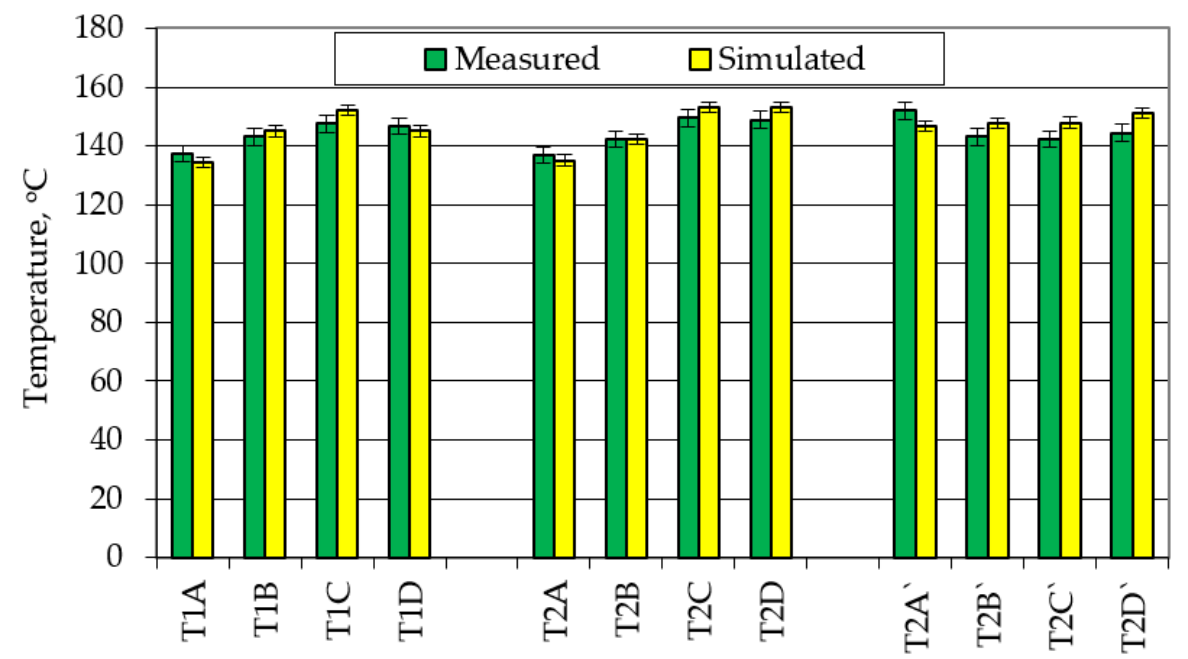

Run number

Figure 17. Results of experimental and modeling final steam temperature.

\section{Conclusions}

A simulation is a convenient tool for developing and scaling up superheated steam flash dryers for tobacco. Even a simple one-dimensional model of isometric monodisperse particle drying was proven useful in predicting the drying process in a CLED. The proposed model is suitable for a full-size CLED where the drying pipe contribution to the overall drying effect is substantial. In a "baby CLED", the share of the drying pipe contribution is smaller and probably comparable to that of the cyclone.

The experimental studies indicate that the higher the drying temperature of the tobacco, the more likely the ignition of the dust cloud, the greater the explosion severity, and the faster the propagation of the explosion flame. Lack of oxygen in the superheated steam dryer led us to us assume that this process is safe. However, there is a probability of occurrence of fire or explosion due to the generation of tobacco dust. The maximum temperature for superheated steam-drying equipment coated with up to $5 \mathrm{~mm}$-thick tobacco layer should not exceed a temperature of $75^{\circ} \mathrm{C}$ lower than the dust-layer minimum ignition temperature, amounting to $215^{\circ} \mathrm{C}$ in the reference case, according to the standard method, or $195{ }^{\circ} \mathrm{C}$ based on the results according to the CRHG method. The results allow the fire and explosion hazards to be minimized and justify the necessity of ensuring comprehensive and frequent removal of accumulated tobacco dust, the respect of drying technological regimes, and the required frequency of maintenance and inspection activities of equipment.

The above work illustrates present-day possibilities in a simulation and its three stages: measure and collect property data, build a model and solve it with readily available mathematical software, and validate the results against industrial process data. The first three stages can be performed by academia; the third is required from industry. As a result of such cooperation, useful simulation models can be created for almost all industrial processes.

Further work is required. First, better sorption isotherms and isobars must be obtained through extensive experiments. Second, a better representation of particles in the model is necessary. For this purpose, an experimental setup for the determination of drag coefficient for ribbon-like particles is under construction in our laboratory. Introducing polydispersity into the model will then be possible. Finally, the drying-rate equation must be experimentally verified. Modification of the setup shown in Figure 10 will allow for the direct measurement of the drying kinetics in controlled conditions. Finally, the model of the expansion process can be introduced and solved simultaneously with the present model. 
Author Contributions: Conceptualization, D.S., R.A. and B.K.; methodology, D.S., R.A. and B.K.; software, R.A.; validation, D.S., M.F.; investigation, R.A., B.K.; data curation, D.S.; writing-original draft preparation, R.A., D.S.; writing-review and editing, M.F., B.K. and M.P.; funding acquisition, R.A., D.S., B.K., M.F. and M.P. All authors have read and agreed to the published version of the manuscript.

Funding: This research was funded by Lodz University of Technology and the Main School of Fire Service in Poland (grant number DOB-BIO9/18/01/2018, financed by the National Centre for Research and Development).

Data Availability Statement: Not applicable.

Conflicts of Interest: The authors declare no conflict of interest.

\section{References}

1. Li, J.; Liang, Q.-C.; Bennamoun, L. Superheated steam drying: Design aspects, energetic performances, and mathematical modeling. Renew. Sustain. Energy Rev. 2016, 60, 1562-1583. [CrossRef]

2. Jewiarz, M.; Wróbel, M.; Mudryk, K.; Szufa, S. Impact of the drying temperature and grinding technique on biomass grindability. Energies 2020, 13, 3392. [CrossRef]

3. Cai, C.; Wang, L.; Wang, G.; Hao, J.; Bai, X.; Wang, Z.; Wang, D. Effects of dry explosion pretreatment on physicochemical and fuel properties of hybrid pennisetum (Pennisetum americanum $\times$ P. purpureum). Bioresour. Technol. 2020, 297, 122508. [CrossRef] [PubMed]

4. Pakowski, Z.; Druzdzel, A.; Drwiega, J. Validation of a model of an expanding superheated steam flash dryer for cut tobacco based on processing data. Dry. Technol. 2004, 22, 45-57. [CrossRef]

5. Kukfisz, B. The potential fire and explosion hazards in biomass co-firing with conventional fossil fuels based on data obtained during testing. E3S Web Conf. 2018, 45, 00039. [CrossRef]

6. Kukfisz, B.; Siuta, D.; Szaferski, W. Analysis of Coal Dust Ignition Deposited in a Layer at Constant and Variable Temperature of Heating Panel-Practical Aspects of Chemical Engineering; Ochowiak, M., Woziwodzki, S., Mitkowski, P.T., Doligalski, M., Eds.; Springer International Publishing: Cham, Switzerland, 2020; pp. 209-215.

7. Adamski, R.; Siuta, D.; Kukfisz, B.; Mitkowski, P.T.; Szaferski, W. Influence of process parameters in superheated steam drying on fire and explosion parameters of woody biomass. Fuel Process. Technol. 2021, 211, 106597. [CrossRef]

8. Markowski, A.S.; Siuta, D. Fuzzy logic approach for identifying representative accident scenarios. J. Loss Prev. Process. Ind. 2018, 56, 414-423. [CrossRef]

9. Le, K.H.; Tran, T.T.H.; Kharaghani, A.; Tsotsas, E. Modeling of superheated steam drying of wood particles. J. Mech. Eng. Res. Dev. 2020, 43, 160-170.

10. Tran, T.T.H. Modelling of drying in packed bed by super heated steam. J. Mech. Eng. Res. Dev. 2020, 43, 135-142.

11. Ono, T.; Yoshida, T. Designing of Dryer in Tobacco Manufacturing Process. Drying' 86 1986, 2, $630-636$.

12. Kiranoudis, C.T.; Maroulis, Z.B.; Marinos-Kouris, D. Mass transfer modeling for virginia tobacco curing. Dry. Technol. 1990, 8, 351-366. [CrossRef]

13. Legros, R.; Alan Millington, C.; Clift, R. Drying of tobacco particles in a mobilised bed. Dry. Technol. 1994, 12, 517-543. [CrossRef]

14. Miyauchi, M.; Miyake, A.; Nakanishi, Y.; Sagara, Y. Characteristics of water adsorption isotherms for materials contained in a box of a tobacco product. Dry. Technol. 1995, 13, 351-370. [CrossRef]

15. Pakowski, Z.; Krupinska, B.; Adamski, R. Prediction of sorption equilibrium both in air and superheated steam drying of energetic variety of willow Salix viminalis in a wide temperature range. Fuel 2007, 86, 1749-1757. [CrossRef]

16. Pakowski, Z.; Krupińska, B.; Adamski, R. Sorption isobars of tobacco materials required for the superheated steam drying processes. Chem. Process Eng. Inz. Chem. Proces. 2006, 27, 507-517.

17. Bandrowski, J.; Kaczmarzyk, G. Gas-to-particle heat transfer in vertical pneumatic conveying of granular materials. Chem. Eng. Sci. 1978, 33, 1303. [CrossRef]

18. Kerekes, B.; Lengyel, A.; Sikolya, L. Thermophysical and transport properties in curing of tobacco. Drying'98 1998, 98, 719-726.

19. Haider, A.; Levenspiel, O. Drag coefficient and terminal velocity of spherical and nonspherical particles. Powder Technol. 1989, 58, 63-70. [CrossRef]

20. Hausbrand, E. Das Trocken Mit Luft Und Dampf, 5th ed.; Springer: Berlin/Heidelberg, Germany, 1920.

21. Pang, L.; Cao, J.; Ma, R.; Zhao, Y.; Yang, K. Risk assessment method of polyethylene dust explosion based on explosion parameters. J. Loss Prev. Process Ind. 2021, 69, 104397. [CrossRef]

22. Eckhoff, R.K. Measurement of minimum ignition energies (MIEs) of dust clouds-History, present, future. J. Loss Prev. Process Ind. 2019, 61, 147-159. [CrossRef]

23. Dyduch, Z.; Majcher, B. Ignition of a dust layer by a constant heat flux-heat transport in the layer. J. Loss Prev. Process Ind. 2006, 19, 233-237. [CrossRef]

24. Meunier, J.; Munz, R.J. Flash drying with superheated steam-A mathematical model. Drying'86 1986, 2, 580-587. 
25. Blasco, R.; Vega, R.; Alvarez, P.I. Pneumatic drying with superheated steam: Bi-dimensional model for high solid concentration. Dry. Technol. 2001, 19, 2047-2061. [CrossRef]

26. Goroshko, V.D.; Rozenbaum, R.B.; Todes, O.M. Hydrodynamics and Heat Transfer in Fluidized Beds; M.I.T. Press: Cambridge, MA, USA, 1966; p. 71.

27. Reay, D.; Bahu, R. Particle velocities in pneumatic conveying dryers. Drying'84 1984, 1, 222-227.

28. Nebra, S.; Silva, M.A.; Mujumdar, A.S. Drying in cyclones-A review. Dry. Technol. 2000, 18, 791-832. [CrossRef]

29. Pakowski, Z.; Bartczak, Z.; Strumillo, C.; Stenström, S. Evaluation of equations approximating thermodynamic and transport properties of water, steam and air for use in cad of drying processes. Dry. Technol. 1991, 9, 753-773. [CrossRef]

30. Markowski, A.S.; Mujumdar, A.S. Drying risk assessment strategies. Dry. Technol. 2004, 22, 395-412. [CrossRef]

31. Markowski, A.S.; Siuta, D. Selection of representative accident scenarios for major industrial accidents. Process Saf. Environ. Prot. 2017, 111, 652-662. [CrossRef] 